\title{
MILLER CHRISTY, NATURALIST AND HISTORIAN
}

C. STUART HOUSTON, 863 University Drive, Saskatoon, Saskatchewan S7N $0) 8$

Robert Miller Christy's important observations in Manitoba and Sas katchewan have been almost forgotten. The story of my investigations into his achievements is long and rather complicated.

In 1975, while preparing my introduction to Ernest Thompson Seton in Manitoba, 1882 - 1892, I contacted Eleanor Pratt, Director of the Ernest Thompson Seton Museum, Boy Scouts of America, at Cimarron, New Mexico. ${ }^{2}$
Pratt mentioned that their museum contained a duplicate copy of Thomas Hutchins' manuscript on Mammals and Birds. She kindly sent me the title page of the proposed Observations on Hudson's Bay which Seton's friend R. Miller Christy had prepared for possible joint publication in England, Canada and the United States in 1910 (Fig. 1).

In October 1985 my wife, Mary, and I tracked down further evidence in the library of the Linnean Society at Bur- 
lington House in London, England. We learned how Christy had answered a query placed in the Journal of Botany in 1921, by the editor, James Britten.' Britten's query, under the title of "An Early Hudson's Bay Collector", was as follows:

"In the Banksian Herbarium are a considerable number of sheets endorsed in Banks's hand, "Hudson's Bay 1773." We had always assumed that these were of Bank's own collecting, and it was only lately that, the matter having attracted notice, it became evident that he never went to Hudson's Bay, nor does his correspondence throw any light on their acquisition ... Who collected in Hudson's Bay in $1773 ?$ ?"

The answer was provided by Miller Christy, in a note titled "An Early Hudson Bay Collector" in the same journal the next year: "In reference to the plants collected in the Territories of the Hudson Bay Company in 1773, and now in the Banksian Herbarium, I had no idea that any such plants existed. They were collected by one Thomas Hutchins, a chief-factor in the service of the Hudson Bay Company, who visited England in or about the year indicated, bringing with him the manuscript of a volume entitled "Observations on Hudson's Bay," which is still preserved in the Library of the Company at its London offices. I have long been interested in this volume, which gives a long and valuable account of Hudson Bay, its history, natives, trade, climate, fauna, flora, etc. Many years ago my friend Mr. Ernest Thompson Seton and myself [Christy] were permitted to have a copy made of it, with a view to its publication under my general editorship, and the help of a specialist in each department of knowledge treated. Unfortunately however, the work, though nearly ready for publication, has not yet been issued. On the outbreak of war, I sent the MS. to Mr. Seton in New York, where he is arranging for its publication. With this volume, Hutchins must have brought some small collections of specimens, including the plants in question; for there is, in the Fish Galleries at the Museum, at least one fish (the typespecimen of some well-known species, if I recollect rightly); and, in the Bird Galleries, there are, I believe, several birds of his collecting. Doubtless before Hutchins returned to Hudson Bay he either sold or presented these collections to Banks. In regard to the plants: it would probably be found, if one referred to Hutchin's MS., that all, or most of them, are described in the botanical section thereof. In the editing of this, I was assisted by the late Prof. John Macoun, of Ottawa, who identified, so far as was possible, the species mentioned by Hutchins; the latter was not in any sense a scientific (scarcely even a popular) botanist. ${ }^{\prime \prime}$

In the note quoted above, Miller was wrong in giving all the credit to Hutchins for the beautifully written and informative nature notes from Hudson Bay, which accompanied a large box of natural history specimens sent back to England in 1772 . For over a century this important manuscript had been ascribed to Thomas Hutchins (17421790), who was the Hudson's Bay Company surgeon at York Factory from 1766 to 1773 and then chief at Albany from 1774 to 1782 . There are at least five slightly different "original" versions extant, four in the Hudson's Bay Company Archives in Winnipeg and one in the Royal Society library in London, England. Subsequent research by Professor Glyndwr Williams has demonstrated that most of the specimens were collected by Andrew Graham (1733-1815). Most of the text was written by Graham in 1772, then copied and added to by surgeon Thomas Hutchins. 
In 1969 the Hudson's Bay Record Society published Andrew Graham's Observations on Hudson's Bay 17671791, edited by Glyndwr Williams, with an introduction by Richard Glover. ${ }^{16}$ Although the two contemporaries had collaborated, Hutchins had copied Graham's notes on 99 species of birds, adding his own for 12 additional species. The collaboration between the two naturalists was sorted out more fully by Glyndwr Williams in the spring 1978 issue of The Beaver, in an article entitled "Andrew Graham and Thomas Hutchins, Collaboration and Plagiarism in 18th Century Natural History ${ }^{\prime \prime}{ }^{7}$

But how did tinis Englishman, Miller Christy, and a North American, Ernest Thompson, come to collaborate in their unsuccessful project to publish the Graham-Hutchins manuscript? What do we know about Christy?

Ernest E. Thompson's family had emigrated from the River Tyne near Newcastle to a farm near Lindsay, Ontario in 1866, just before Ernest's sixth birthday. Four years later the family moved to Toronto. Soon after his 19th birthday, Ernest went to London, England, to study art for two years. Although his autobiography claims that he added the historic family name of Seton on his 21 st birthday, he wrote his first articles as Ernest E. Thompson and later as Ernest Seton-Thompson. Only late in 1901 did he finally and legally assume the name by which he became the world's most successful nature author, Ernest Thompson Seton. For the reader's benefit, I will refer to him simply as Seton.

On weekends Seton would visit with his cousin by marriage, George Porteous, at Saffron Walden, 42 miles out of London. One of Porteous' subordinates was a young man, R. Miller Christy, nine months younger than
Seton, who shared his natural history interests. Seton and Christy went on many field trips together.

Seton's Manitoba observations are readily available in Ernest Thompson Seton in Manitoba, 1882 - 1892, published by the Manitoba Naturalists Society. ${ }^{1}$ A superb biography, Black Wolf, by Betty Keller, appeared in 1984, and another, The Chief, Ernest Thompson Seton and the Changing West, by $H$. Allen Anderson, was published in 1986. Here is an attempt to place the other partner in the failed publishing effort, Miller Christy, in proper biographical perspective.

Robert Miller Christy was born near Chelmsford in Essex, England, in May 1861. (He ceased using "Robert" or even the initial " $R$ " in the late 1880s.) From childhood he evinced a remarkable interest in natural history, beginning his early collection of conchological and ornithological specimens while at Bootham School in York.

As a young man, Christy was selected by the James Hack Tuke Emigration Committee to go to the United States to assist the settling of starving families sent out following the Irish Potato Famine of $1881-82 .{ }^{14} \mathrm{He}$ left Liverpool on 5 July 1883 and arrived in New York on 14 July. Following the completion of his duties, he continued on to visit Manitoba and his friend, Ernest E. Thompson, who had moved the previous year to his brother's farm at Carberry.

On 8 and 10 August, Seton and Christy visited Percy Criddle, who had settled the previous year near the confluence of the Souris and Assiniboine Rivers, southeast of Brandon. Seton and Christy made up study skins of birds and mammals. Seton tells that they demonstrated their techniques to 
the Criddle sons, Norman and Stuart, only 8 and 5 years of age, both of whom later became well known naturalists.

On 18 September Christy visited Brandon (population then under 4000) for the first time. He left Brandon on I October for the Provincial Agricultural Exhibition at Portage La Prairie (population 5000) for two days. On 18 October he went to Winnipeg. Later in the month he went to Brandon, Shoal Lake, Birtle, Fort Ellice and then south to Elkhorn.

Christy's article in Nature on 3 January 1884 concerned the absence of earthworms from the prairies of the Canadian North-west, between Winnipeg and the Rockies, whereas they abounded at Toronto and in other parts of Ontario. ${ }^{3}$ [Earthworms had already been introduced from Europe to Ontario and soon were brought by settlers to Manitoba.] Possible reasons for their absence were the great cold of winter and the prevalence of prairie fires in spring and autumn. He quoted Charles Darwin's statement that earthworms could descend three or four or even seven or eight feet below the surface in cold countries. Christy concluded with the suggestion that the ground squirrels

with their extensive burrows may to some extent have accomplished the natural cultivation of the soil in the way worms were accustomed to do elsewhere.

Christy returned in 1884, coming by train via Minneapolis-St.Paul and crossing the border at Pembina-Emerson on 13 June. He took the new railroad west as far as Maple Creek where he shot a Solitary Sandpiper and a Brewer's Blackbird on 10 July and also found a Catbird nest at Moose Jaw. He noted how the Cliff Swallows quickly built nests around the watertanks and under many of the bridges within a year of the railway being constructed. The Barn Swallow was as yet very rare.

During his trip west in 1884, Christy stopped at Indian Head to visit the famous 54,000 acre Bell Farm, the property of the Qu'Appelle Valley Farming Company formed in 1881 and managed by Major W.R. Bell. Christy provided detailed information about this gigantic farm: it had been purchased for $\$ 1.25$ per acre on the condition that not less than 4000 acres were to be broken and brought under cultivation annually for 5 years. In 1882, 2400 acres had been broken and in 1883 half of this acreage was sown with oats and the other half with wheat. The wheat gave an average yield of 19.5 bushels per acre and sold for $\$ 1.01$ per bushel. In 1883, 4600 additional acres were broken so that in 1884, 5500 acres were sown with wheat, 1200 with oats and 300 with flax. The farm kept 193 horses for the plowing. They had 22 binders by Deering and 25 by Harris of Brantford. During the summer 170 men were employed at $\$ 30$ per month and board. The cost of producing a bushel of wheat was 33 cents and the freight to Montreal was another 32 cents. However, the company was at his time of writing dividing their large estate into 250 separate farms of 213 acres each. ${ }^{2}$

Christy's 208-page book, Manitoba Described, was published by Wyman and Son's in London in 1885, as an incentive to those thinking of settling in the new province. He told of the vast flocks of waterfowl in spring and fall migration, mentioning thousands of ducks on the Rapid City trail on 11 and 12 October. ${ }^{4} \mathrm{He}$ also published "Notes on the Birds of Manitoba" in The Zoologist for April 1885, reprinted in The Ornithologist and Oologist in May and June. ${ }^{5} \mathrm{His}$ rambling account of his travels mentioned 56 species of birds. The American Crow was uncommon in 
summer, but became more noticeable when it formed flocks in fall. A loose group of 30 kestrels passed through Carberry on 7 September 1884. A friend shot a Passenger Pigeon on 30 August 1884 , the only specimen that he saw. Sandhill Cranes still bred "pretty commonly" in the swamps of the Carberry sandhills and along the Upper As siniboine River. Last-seen dates for fall migration were given for a number of species.

On his return to England Christy exhibited to the Linnean Society a collection of Lepidoptera and Hymenoptera, and presented 156 specimens. He gave a paper "On the Methodic Habits of Insects when Visiting Flowers" and another "On the power of penetrating the bodies of animals possessed by the seed Stipa spartea," the former of which was published in the Linnean Society Journal, and the latter in Knowledge. Christy described how "no known seeds, probably, employ means more atrociously and barbarously cruel than those employed by the seed of a species of grass, known as Stipa spartea, which is excessively common over a large extent of the North American prairies. Briefly described, this villainous instrument is nothing more or less than an automatic vegetable corkscrew, with an exceedingly sharp point, and capable, by its own action, of boring itself into the bodies of living sheep and other animals, and of finally killing them by so doing. The plant ... inhabits the drier portions of the plains and prairies of the west."

Miller Christy made his third visit in 1887. He climbed to a Great Horned Owl nest along the Little Whitesand River near present Yorkton on 5 May and found two young owls with 20 dead Northern Pocket Gophers lined up around the nest. On 18 May at Shoal Lake, Manitoba, he visited the pelican colony and watched a Thirteen-lined
Ground Squirrel trying to catch a Vesper Sparrow.

In The Field for 14 April 1888, after returning from his third trip, Christy wrote a long essay about "Sport in Manitoba", filling three columns of tiny print on a very large page. ${ }^{7} \mathrm{He}$ described the opportunities for hunting, telling how the Greater Prairie Chicken appeared at Pembina on the United States boundary in 1883, reaching Winnipeg and Portage La Prairie in 1884. The Upland Sandpiper was then "abundant ... its long-drawn mellow whistle ... one of the most familiar and melodious natural sounds heard on the prairies." An excellent table bird, it was often shot by gunners. Christy recommended that naturalists take a trip to Shoal Lake, 25 miles from Stonewall, [not to be confused with the present village of Shoal Lake] where F.W. Robertson had a hotel and could take visitors in a small steam launch to an island where hundreds of pelicans nested and another with cormorants. Willow Ptarmigan were then "abundant" in winter as far south as Lake Manitoba. Christy told of lakes "black with ducks" in September and October. Perhaps his most important record was the nest of a Hooded Merganser in a hollow tree, evidently found near Carberry.

His major paper "Why are the Prairies Treeless?" was published in the Royal Geographical Society Proceedings for 1892. Christy disagreed with Professor Whitney of lowa who said that the Manitoba part of the prairies was treeless because the area had been a lake bed with extreme fineness of the soil particles. Christy believed that fire was the explanation: "... by far the larger portion of the whole area of the prairies gets burned over annually." At the time of his visit he noted that even two narrow wheel marks of carts with grass growing between helped to stop fires. 
"Young trees spring up annually, only to be at once burned." He quoted his friend, Ernest E. Thompson [Seton]: "If a piece of prairie, almost anywhere, be protected for two consecutive years, it will be found covered with a growth of popular and willows; therefore I conclude that, but for the fires, the whole country would be covered with bush." Christy noted that the aspen "have great vitality in their roots and repeatedly send up fresh shoots after the annual fires, until death from exhaustion ensues." But "growth is slow and destruction by fire is swift." Water and sandhills equally stopped fire; good clumps of spruce grew in the sandhills south of Carberry. The subsidiary causes of the fires were the "exceptional dryness, the relatively level ground and the high winds on the prairies."10

Christy settled down as a partner in the printing firm of Hayman, Christie and Lilley Ltd.in Chelmsford. In 1889, he was elected a Fellow of the Linnean Society of London, and thereafter used "F.L.S." after his name. In 1890, he wrote The Birds of Essex, the chief authority on the topic for 30 years, and the following year, A Catalogue of Local Lists of British Birds, Arranged Under Counties. ${ }^{8}$ He served as president of the Essex Naturalists' Club from 1905 to 1907, and from 1910 until his death was one of the permanent vice-presidents. From 1917 to 1919 he was editor of The Essex Naturalist. He was also a member of council of the Essex Archaeological Society. He was knowledgeable about the history of arctic exploration and edited important books for the Hakluyt Society, including The Voyages of Captain Luke Foxe of Hull, and Captain Thomas James of Bristol, in Search of a North-West Passage, in 1631-32, and On 'Busse Island', one of the Lost Islands of the Atlantic. His last article, "Captain William Hawkeridge and His Voyage in Search of a North-west Passage in
1625", appeared in Mariner's Mirror in 1927. Christy also wrote about banking, clocks, brasses, trade signs and Roman roads. He compiled the Handbook for Essex County. He was one of the founders of, and a frequent contributor to, The Essex Review. Natural History notes were published in The Essex Naturalist, Field, Zoologist, Journal of Botany, Journal of Ecology, New Phytologist, and Journal of the Linnean Society. He offered hospitality to naturalists at his bachelor's home at Chignal St. James, near Chelmsford. He died on 25 January 1928, following surgery. ${ }^{15}$

Had Christy and Seton published Andrew Graham's manuscript, they would have followed all their predecessors and given inappropriate credit to Thomas Hutchins. Perhaps it is as well that this project awaited the scholarly attention of Glyndwr Williams and Richard Glover in 1969. Nevertheless, Christy's researches concerning northern and western Canada remain a useful contribution worthy of our attention. Christy's observations, and more particularly those of his friend Seton, give us an important and fairly complete picture of the bird life in Manitoba at the time of beginning settlement.

'BRITTEN, J. 1921. An early Hudson's Bay collector. Journal of Botany 59:238.

${ }^{2}$ CHRISTY, R.M. 1884. Notes on a visit to the Bell Farm, Assiniboia. The Field 64:899.

'CHRISTY, R.M. 1884. On the absence of earthworms from the prairies of the Canadian North-west. Nature 29:213-214.

${ }^{4}$ CHRISTY, R.M. 1885. Manitoba described. London: Wyman \& Sons.

${ }^{5}$ CHRISTY, R.M. 1885. Notes on the birds of Manitoba. The Zoologist, series 3, 9:121133. Reprinted in Ornithologist and Oologist 10:76-78,91-94. 
- CHRISTY, M. 1888. A botanical atrocity. Knowledge 11:247-249.

CHRISTY, M. 1888. Sport in Manitoba. The Field, 14 April, 543-544.

"CHRISTY, M. 1890. The birds of Fssex. Essex Field Club Special Memoirs, vol. 2. $302 \mathrm{pp}$.

${ }^{9}$ CHRISTY, M. 1891. A catalogue of local lists of British birds arranged under counties. London: Mayman, Christy \& Lilly. 42 pp.

"CHRISTY, M. 1892. Why are the prairies treeless? Royal Geographical Society Proceedings 14:78-100

'CHRISTY, M. 1922. An early Hudson Bay collector. Journal of Botany 60:336-337.

${ }^{12}$ HOUSTON, C.S. 1980. Introduction, vxv, in Ernest Thompson Seton in Manitoba,
1882-1892. Winnipeg: Manitoba Naturalists Society.

"THOMPSON [-SETON], E.E. 1891. The Birds of Manitoba. Proceedings United States National Museum 13:457-643.

14THOMPSON, P. 1927-28. Robert Miller Christy. Proceedings of the Linnean Society of London, 1927-28, 112-113.

15 THOMPSON, P. 1929. Miller Christy, F.L.S., an obituary. Essex Naturalist 22:110112 , plate 8.

"WILLIAMS, G., ed. 1969. Andrew Graham's observations on Hudson's Bay, 1767-91. London: Hudson's Bay Record Society. $423 \mathrm{pp}$.

17 WILLIAMS, G. 1978. Andrew Graham and Thomas Hutchins: Collaboration and plagiarism in 18th-century natural history. Beaver 308.4:4-14.

Within the area of the $72 \mathrm{~N}$ Kindersley mapsheet $(1: 250,000$ scale) we placed 107 green bands on nestling Swainson's Hawks, in addition to the regular aluminum band on the other leg. Most of these nests were found by Jean Harris, Dean Francis or Bill Marjerrison.

Frankly, we would feel fortunate to locate four of the 107 as breeding birds in 1989, because nestlings disperse so widely, and because few breed when only one year old. If you can help us to locate just a few breeding birds of each species, with color bands, that can be followed year by year, this would have the potential to add much more to knowledge than the simple banding program of past years. In addition, we hope the extra color band, with easily readable letters or numbers on the other leg, will more than double, perhaps quadruple, the recoveries obtained from the Swainson's Hawk wintering grounds in Argentina and the Osprey wintering grounds in Ecuador and Columbia. 